\title{
PENERAPAN FRAMEWORK LARAVEL PADA APLIKASI HRIS (HUMAN RESOURCE INFORMATION SYSTEM)
}

\author{
Muhammad Ma'ruf Holid Junaedi ${ }^{1}$, Sari Susanti ${ }^{2}$, Ade Mubarok ${ }^{3}$ \\ ${ }^{1}$ Universitas Adhirajasa Reswara Sanjaya \\ e-mail: marufben@gmail.com \\ 2Universitas Adhirajasa Reswara Sanjaya \\ e-mail: sarisusanti@ars.ac.id \\ 3Universitas Adhirajasa Reswara Sanjaya \\ e-mail: adem@ars.ac.id
}

\begin{abstract}
Abstrak
Sumber daya manusia merupakan sumber daya organisasi yang perlu dikelola dengan efisien dan efektif. Banyaknya informasi yang harus dikelola terkait sumber daya manusia memunculkan permasalahan tingkat kompleksitas yang tinggi. Pentingnya pengaturan sumber daya manusia yang sangat kompleks pada suatu perusahaan membuat perusahaan diharuskan membentuk sebuah divisi baru yaitu Human Resource Department atau Personalia. Tanpa sebuah aplikasi, bagian HRD mempunyai beberapa kesulitan berupa pengelompokkan data, penghitungan jumlah kehadiran, uang transport dan makan kemudian terakhir slip gaji karyawan dan pencetakkan laporan slip gaji. Untuk menangani permasalahan tersebut perlu diterapkan aplikasi Human Resources Information System (HRIS). Sebuah modul yang penting yang terdapat pada sistem ini adalah payroll atau pengajian. PT Octagon Studio Ltd merupakan startup asal Bandung, salah satu perusahaan yang sering kali mengalami masalah terkait pengelolaan manajemen sumber daya manusia yang kurang baik. Selama ini proses perhitungan gaji yang dilakukan oleh sistem yang ada, masih tergolong belum efektif. Jadi proses perhitungan gaji dilakukan satu persatu tiap pegawai. Sehingga waktu yang diperlukan untuk melakukan perhitungan gaji membutuhkan waktu lama. Pada pengajuan cuti, masih dilakukan secara manual sehingga pengelolaannya belum optimal dan prosesnya cukup lambat. Selain itu sulitnya mendapatkan informasi seperti data kepegawaian dan jumlah cuti yang tersedia untuk masing-masing pegawai. Aplikasi HRIS ini dibuat menggunakan model waterfall yang mencakup: analisis, desain, pengkodean dan pengujian dengan mengunakan PHP Framework Laravel dan MySQL sebagai database. Terkait masalah tersebut diperlukan aplikasi HRIS yang diharapkan dapat membantu perusahaan dalam perhitungan gaji karyawan secara bersamaan dan pengelolaan data pegawai.
\end{abstract}

Kata Kunci: Sistem Informasi, Human Resource, Laravel.

Abstract
Human resources are organizational resources that need to be managed efficiently and
effectively. The amount of information that must be managed related to human resources raises
the problem of a high level of complexity. The importance of highly complex human resource
management in a company makes the company is required to form a new division that is the
Human Resource Department or Personnel. Without an application, the HRD section has some
difficulties in the form of grouping data, calculating the amount of attendance, transport and food,
then finally employee salary slips and printing salary slip reports. To deal with these problems the
Human Resources Information System (HRIS) application needs to be applied. An important
module contained in this system is payroll or recitation. PT Octagon Studio Ltd is a startup from
Bandung, one of the companies that often experiences problems related to poor human resource
management. During this time the salary calculation process carried out by the existing system,
is still classified as not effective. So the salary calculation process is done one by one per
employee. So the time needed to do salary calculation takes a long time. In applying for leave, it
is still done manually so that the management is not optimal and the process is quite slow. In
addition, it is difficult to get information such as staffing data and the number of leave available
for each employee. This HRIS application was created using the waterfall model which includes:

Naskah diterima 27 Juli 2020; direvisi 10 Agustus 2020; diterbitkan 31 Agustus 2020 
analysis, design, coding and testing using PHP Framework Laravel and MySQL as a database. Related to this problem required HRIS application which is expected to help companies in calculating employee salaries simultaneously and managing employee data.

Keywords: Information System, Human Resource, Laravel.

\section{Pendahuluan}

Sumber daya manusia merupakan salah satu yang memiliki peran penting dalam sebuah perusahaan hal tersebut karena karyawan adalah seseorang yang menggunakan serta mengelola sumber daya lainnya untuk menjalankan proses bisnis perusahaan. (Frangky \& Devitra, 2016).

Pada bidang manajemen, telah digambarkan bahwa salah satu elemen dalam organisasi adalah sumber daya manusia. SDM adalah sumber daya organisasi yang harus dikelola secara efisien dan efektif. Banyaknya jumlah informasi yang harus dikelola berhubungan dengan SDM sehingga memunculkan permasalahan dengan tingkat kompleksitas tinggi (Muhammad \& Niki 2018).

Human Resource Department atau Personalia adalah sebuah divisi yang berfokus dalam penyelesaian masalah SDM. (Tjandra, \& Tambunan, 2019). Tanpa sebuah aplikasi, menurut (Welim \& Iqbal, 2017) bagian Human Resources Department mempunyai beberapa kesulitan berupa pengelompokkan data,penghitungan jumlah kehadiran, uang transport dan makan kemudian terakhir slip gaji karyawan dan pencetakkan laporan slip gaji sering terlambat.

Untuk menangani permasalahan tersebut perlu diterapkan aplikasi Human Resources Information System (HRIS). HRIS (Human Resource Information System) adalah sebuah sistem informasi yang menangani permasalahanpermasalahan yang berkenaan dengan pengelolaan sumber daya manusia pada sebuah organisasi (perusahaan) (Jonni \& Husain, 2016).

Sebuah modul yang penting yang terdapat pada sistem ini adalah payroll atau pengajian. Sistem payroll dapat digunakan untuk menstandarisasi cara perusahaan menangani kalkulasi (penghitungan) dan pengolahan (processing) pembayaran gaji (payrol/). Sistem payroll dapat digunakan tidak hanya untuk menghitung uang yang berkaitan dengan pegawai, namun juga menyediakan kemudahan penyimpanan record yang akurat. Pada dasarnya, software payroll dapat membantu mempersingkat proses keseluruhan, membuat pengelolaan payroll lebih hemat waktu dan tidak rumit. (Tjandra, \& Tambunan, 2019).

Laravel merupakan sebuah model MVC web development framework yang dirancang untuk menambah kualitas Software dengan memangkas biaya pengembangan serta perbaikan dan dapat pula meningkatkan produktifitas suatu pekerjaan. Memiliki sintak bersih juga fungsional sehingga memiliki dapat mempersingkat waktu implementasi (Luthfi, 2017). Penggunaan laravel juga pernah digunakan pada penelitian (Susanti, Junianto \& Rachman, 2017).

Berdasarkan hal tersebut aplikasi HRIS perlu diterapkan di perusahaan salah satunya PT Octagon Studio Ltd merupakan startup asal Bandung, salah satu perusahaan yang sering kali mengalami masalah-masalah terkait pengelolaan manajemen sumber daya manusia yang kurang baik. Selama ini proses perhitungan gaji yang dilakukan oleh sistem yang ada, masih tergolong belum efektif. Jadi proses perhitungan gaji dilakukan satu persatu tiap pegawai. Sehingga waktu yang diperlukan untuk melakukan perhitungan gaji membutuhkan waktu lama. Pada pengajuan cuti, masih dilakukan secara manual sehingga pengelolaannya belum optimal dan prosesnya cukup lambat- Selain itu sulitnya mendapatkan informasi seperti data kepegawaian dan jumlah cuti yang tersedia untuk masing-masing pegawai.

\section{Metode Penelitian}

\subsection{Metode Pengumpulan Data}

Pada tahap ini dijelaskan metode pengumpulan data yang dilakukan oleh penulis adalah:

\section{a. Observasi}

Pengumpulan data diperoleh dengan melakukan penelitian di PT Octagon Studio Ltd secara langsung ke bagian HRD untuk mendapat gambaran yang jelas mengenai sistem yang berjalan dan mencatat hasil observasi yang diperoleh. 
b. Wawancara

Pengumpulan data diperoleh berdasarkan pembicaraan dengan HR Manager untuk mengetahui informasi yang dibutuhkan untuk membangun aplikasi HRIS.

c. Studi Pustaka

Pengumpulan data diperoleh dari buku, jurnal penelitian, sumber-sumber tertulis dan eletronik, yang berkaitan dengan penulisan skripsi dan dapat dijadikan acuan untuk membangun aplikasi.

\subsection{Tahapan Penelitian}

Model pengembangan sistem menggunakan metode waterfall. Model waterfall merupakan model pengembangan Software yang banyak digunakan. Alasannya karena model ini memiliki sifat linear yang dimulai dari tahapan analisis kebutuhan sampai dengan tahap pemeliharaan. Tahapan berikutnya tidak akan dulu dilakukan sebelum tahap sebelumnya selesai dilakukan dan tidak dapat mengulang Kembali ke tahap sebelumnya. (Susanto \& Andriana, 2016).

Sistem waterfall memiliki tahapantahapan sebagai berikut:

a. Analisa Kebutuhan Sistem

Pada tahap ini melakukan analisis terhadap sistem yang berjalan dan menspesifikasikan kebutuhan sistem untuk kebutuhan perancangan sistem informasi yang diusulkan.

b. Desain

Pada tahap ini membuat desain untuk sistem yang diusulkan meliputi perancangan program, membuat Entitiy Relationship Diagram (ERD), Logical Relationship Structure (LRS), Unified Modeling Language (UML), dan User Interface (UI).

c. Code generation

Pada tahap ini melakukan penerapan rancangan sistem dengan membuat kode-kode program yang merupakan hasil rancangan sistem yang diusulkan.

d. Testing

Pada tahap ini melakukan pengujian terhadap program yang sudah dibuat untuk memastikan semua perintah dan fungsi yang ada telah diuji coba dan menghasilkan keluaran yang sesuaai dengan yang diingikan.

e. Support

Pada tahap ini merupakan tahap terakhir untuk pemeliharaan data-data secara berkelanjutan yang ada di sistem yang sudah dibuat.

\section{Hasil dan Pembahasan}

Pada tahap ini akan dijelaskan dalam beberapa tahapan.

\subsection{Analisa Proses Bisnis}

Berdasarkan hasil

wawancara

diketahui bahwa proses bisnis pada sistem bisnis yang sedang berjalan di PT Octagon

Studio Ltd, sebagai berikut:

1. Karyawan melakukan absensi

2. Mesin finger print akan merekam data kehadiran karyawan.

3. Apabila karyawan mengajukan cuti, harus dengan persetujuan Manajer,

4. HRD akan merekap data kehadiran karyawan berdasarkan data finger print dan pengajuan cuti atau ijin.

5. HRD akan menghitung jumlah data kehadiran setiap karyawan.

6. Keuangan akan menghitung gaji pegawai berdasarkan jumlah data kehadiran setiap karyawan.

7. Keuangan melaporkan hasil perhitungan gaji setiap karyawan

8. HRD akan membuat slip gaji untuk setiap karyawan

9. Karyawan menerima slip gaji.

\subsection{Perancangan}

Pada peneparan Framewok Laravel pada Aplikasi HRIS yang di usulkan terdapat beberapa fitur atau menu yang sesuai dengan kebutuhan sistem yang digunakan antara lain:

a. Menu login (memulai akses untuk masuk ke dalam sistem)

b. Menu dashboard (menampilkan halaman utama)

c. Menu data karyawan ( mengelola data penduduk)

d. Menu data jabatan ( mengelola data kartu keluarga)

e. Menu data kehadiran (mengelolah data rekap kehadiran pegawai)

f. Menu data gaji (mengelola data gaji pegawai)

g. Menu data lembur (mengelola data lembur pegawai)

\subsubsection{Use case Diagram}

Use case diagram menggambarkan sebuah interaksi antara satu atau lebih aktor dengan sistem infomasi yang akan dibuat. Use case digunakan untuk mengetahui fungsi apa saja yang ada dalam sebuah sistem informasi dan siapa saja yang berhak 
menggunakan fungsi-fungsi tersebut.Berikut merupakan gambaran Use Case Diagram dari Aplikasi HRIS:

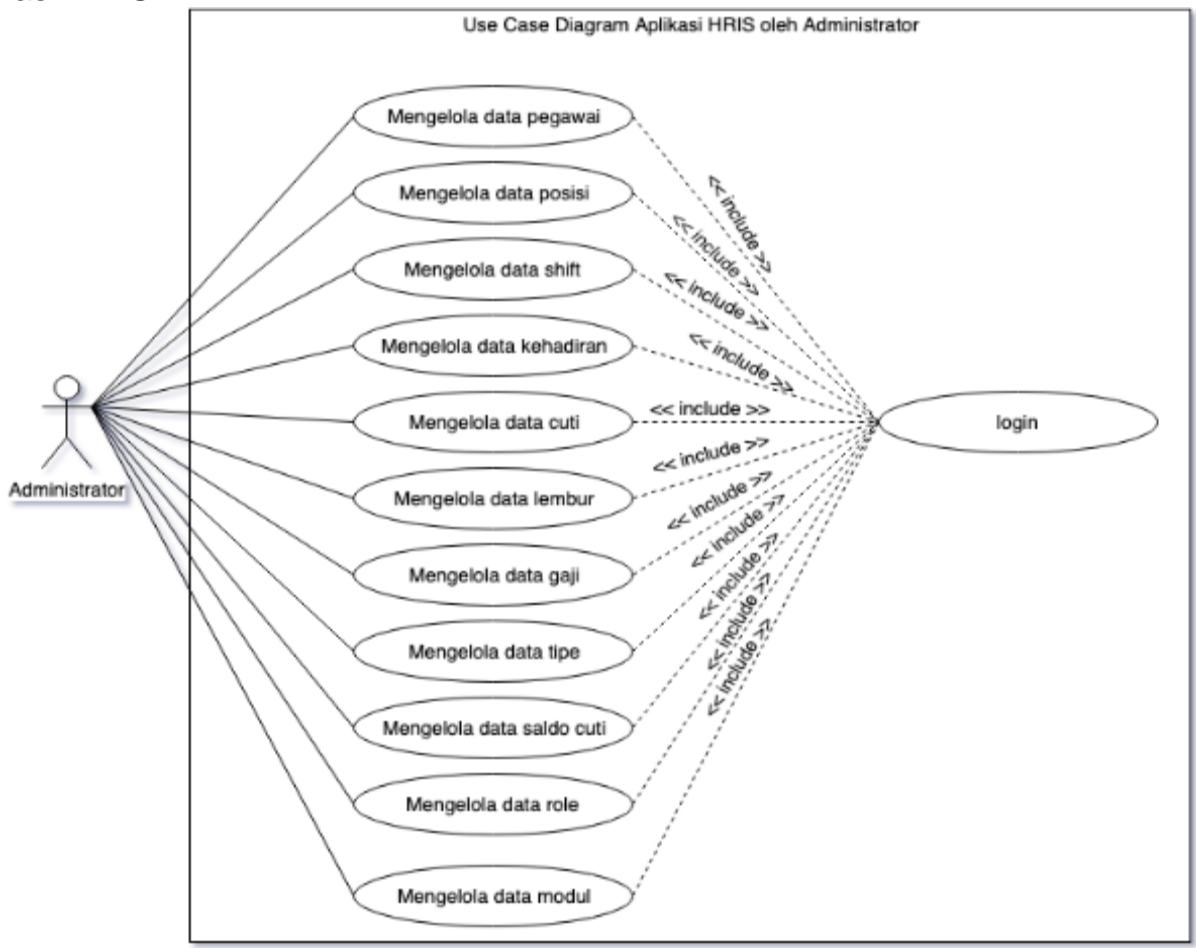

Gambar 1. Use case Aplikasi HRIS oleh Administrator

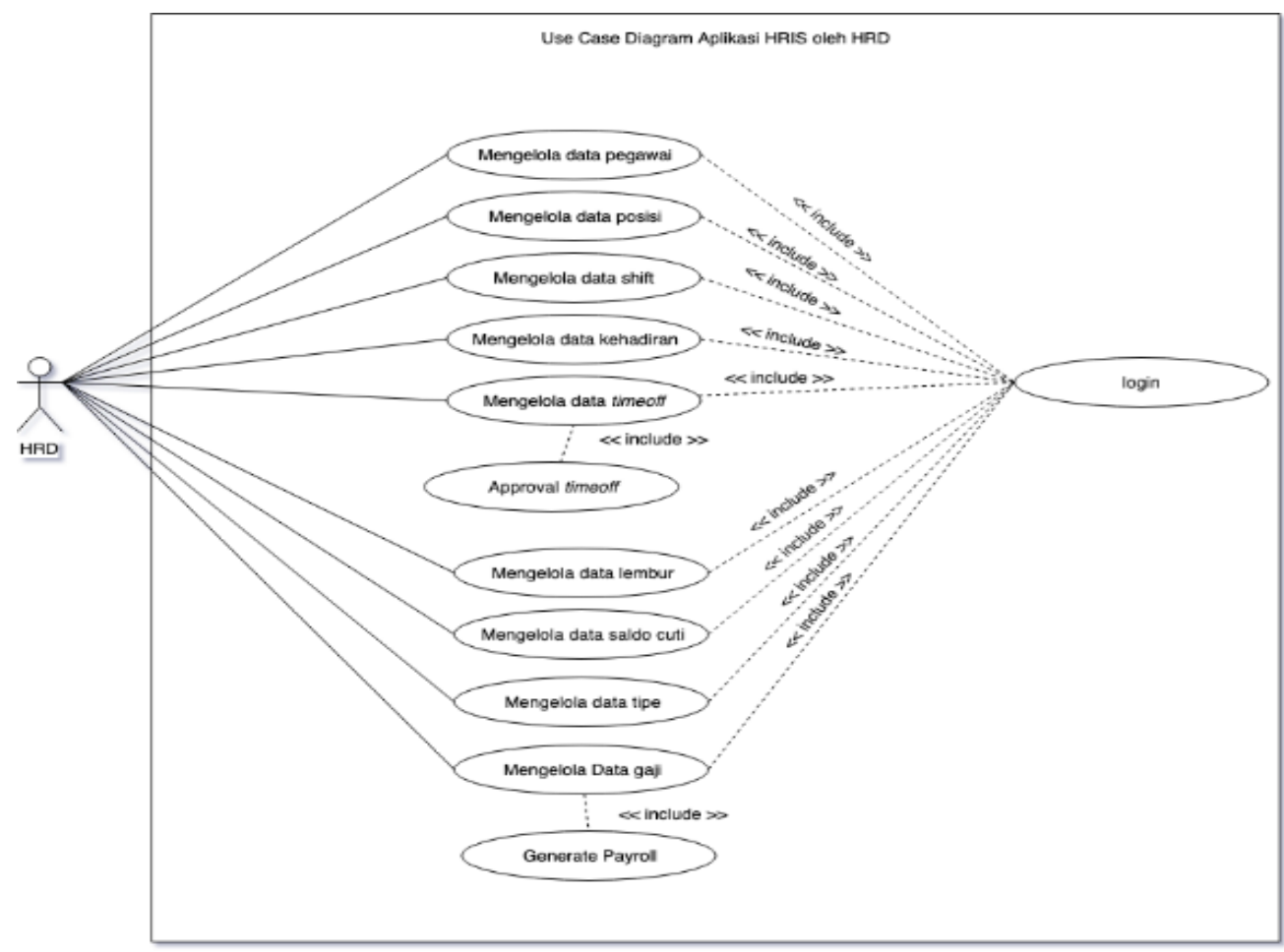

Gambar 2. Use case Aplikasi HRIS oleh HRD 


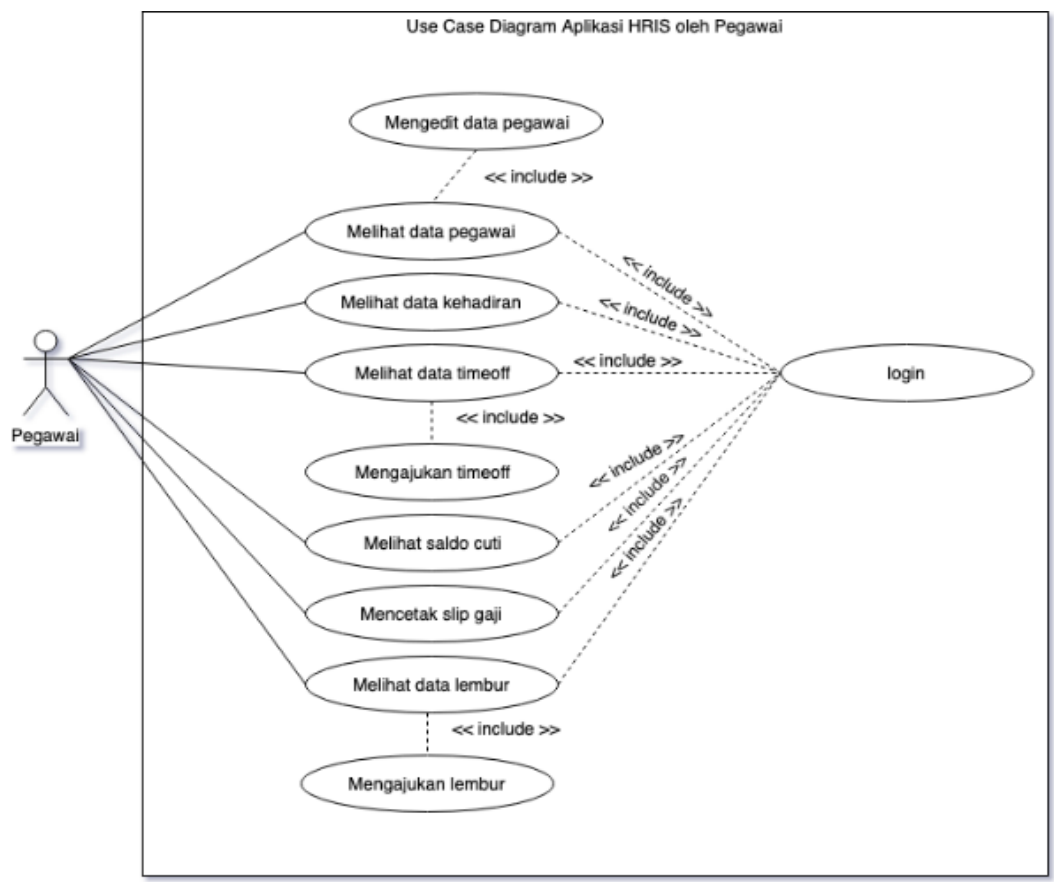

Gambar 3. Use case Aplikasi HRIS oleh Pegawai

\subsubsection{Activity Diagram}

Diagram aktivitas atau activity diagram menggambarkan workflow (aliran kerja) atau aktivitas dari sebuah sistem atau proses bisnis atau menu yang ada pada perangkat lunak. Berikut merupakan rangkaian Activity Diagram pada Aplikasi HRIS:

1. Activity Diagram Mengelola Pegawai oleh Administrator

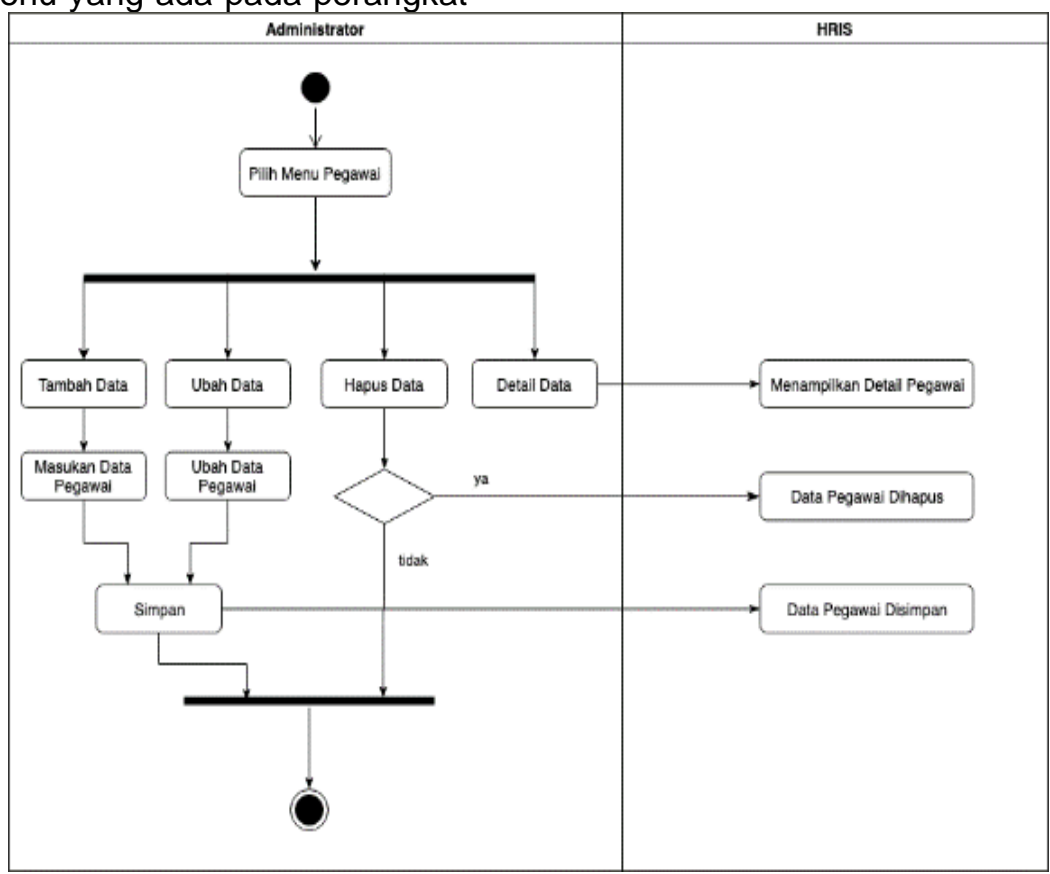

Gambar 4. Activity Diagram Mengelola Pegawai oleh Administrator 
2. Activity Diagram Mengelola Shift oleh Administrator

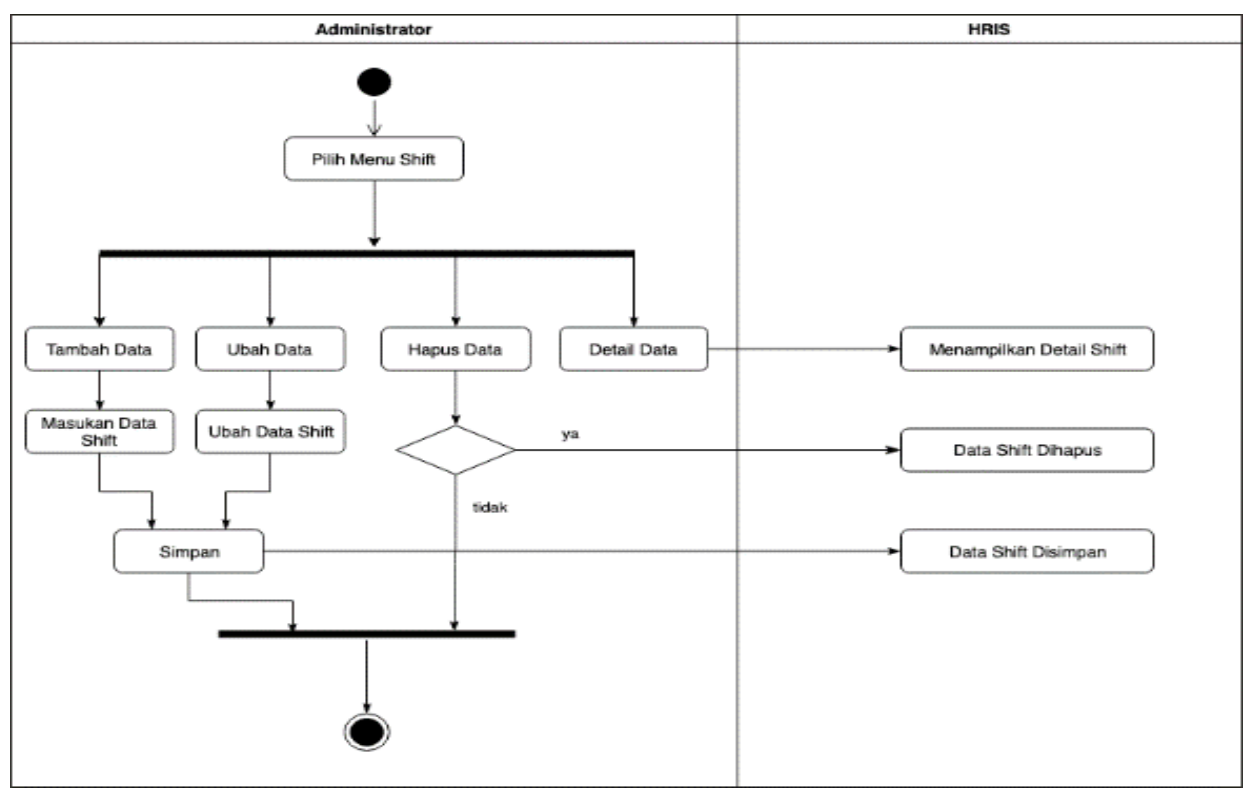

Gambar 5. Activity Diagram Shift oleh Administrator

\subsection{Desain}

Tahapan ini akan menjelaskan tentang desain database, desain software

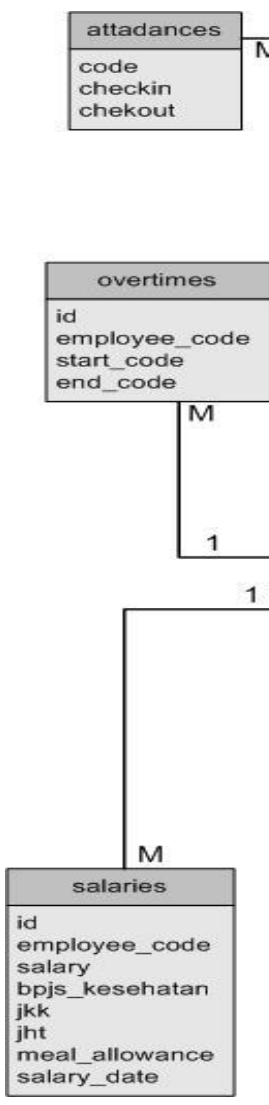

M

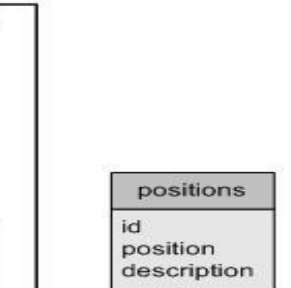

$1 \quad 1$ employees

code
fingerprint id first name last_name email identity_type identity_no postal_code place of birth birth_date phone martial status blood_type blood_typ
religion shift_code password role_id scription

\section{(n)} \begin{tabular}{|l|}
1 \\
\hline
\end{tabular} architecture dan desain interface dari sistem yang sedang dibuat

\subsubsection{Database LRS (Logical Record Structure)}

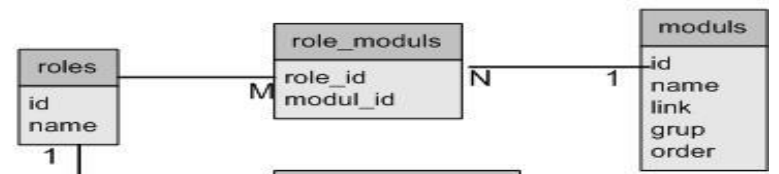
checkin
checkout

1 id

alance_timeoffs ceated_at update at

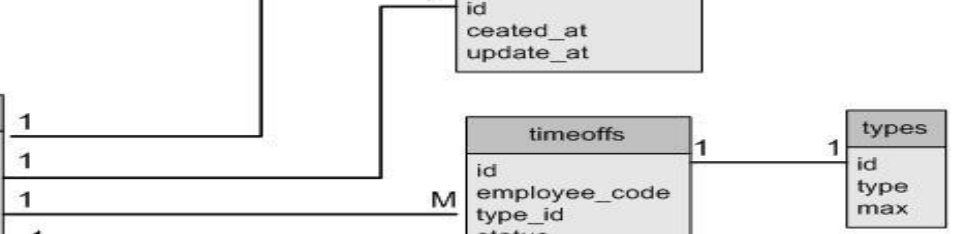
\begin{tabular}{ll}
1 & M \\
\hline 1 & $\begin{array}{l}\text { employ } \\
\text { type_id } \\
\text { status } \\
\text { descrip }\end{array}$ \\
\hline
\end{tabular} description

filart_date end_date

\begin{tabular}{|l|}
\hline \multicolumn{1}{|c|}{ payrolls } \\
\hline id \\
employee_code \\
npwp_daate \\
npwp_daccount \\
bank_accolatan_no \\
salary \\
bpjs_kesehatan_no \\
bpjs_ketenagakerjaan_no \\
\hline
\end{tabular}

Gambar 6. Logical Record Structure 


\subsection{User Interface}

Berikut adalah rancangan antar muka pengguna yang memperlihatkan bagaimana bentuk dari perangkat lunak yang akan di bangun nantinya berdasarkan struktur aplikasi yang sudah dibuat.

1. Halaman Login

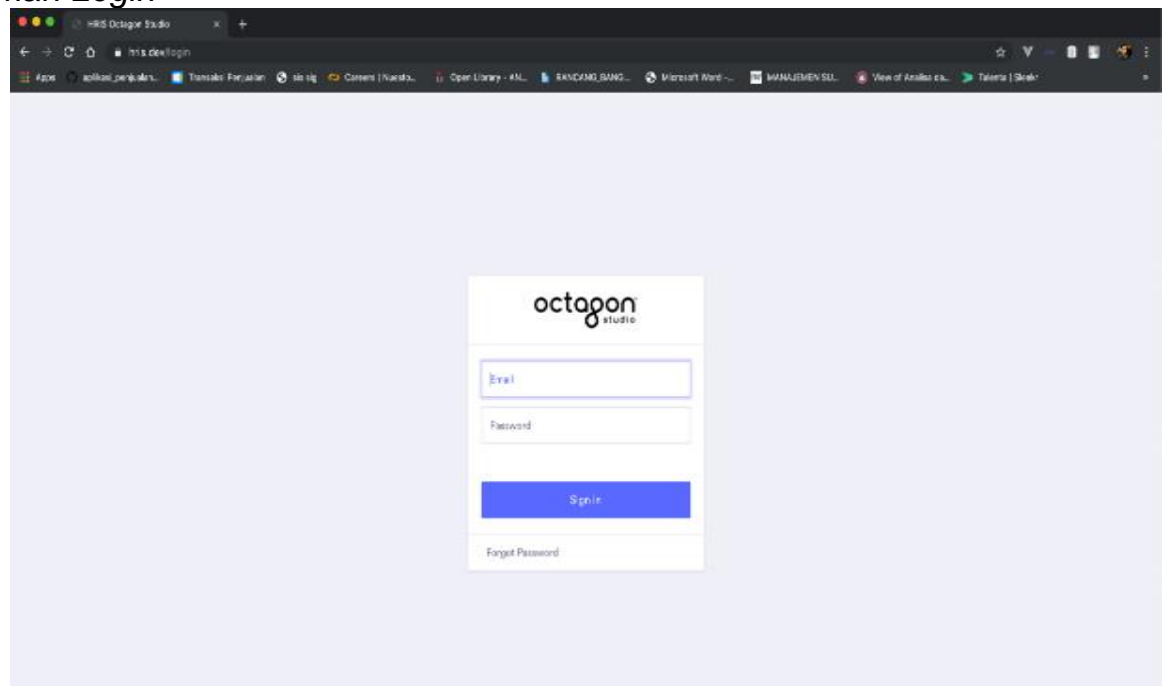

Gambar 7. Halaman Login

2. Halaman Employee

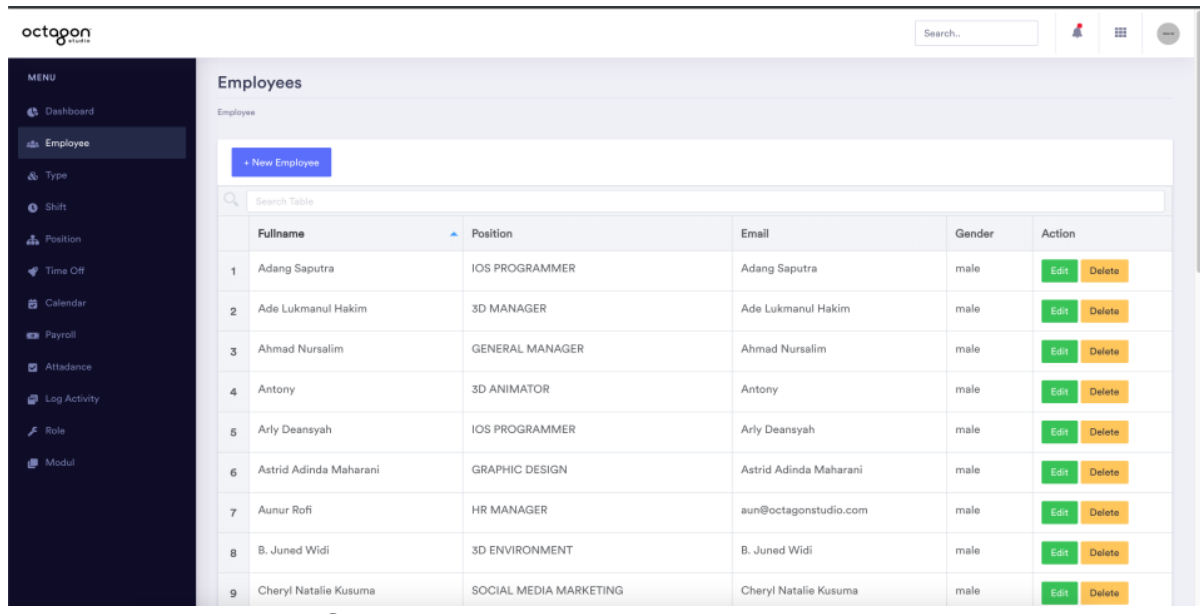

Gambar 8. Halaman menu Employee

\subsection{Support}

Menjelaskan tentang spesifikasi hardware dan software yang akan digunakan untuk menjalankan sistem yang dibuat.

\subsubsection{Publikasi Web}

Proses publikasi HRIS ini meliputi pemilihan domain dan pemasangan domain ke Virtual Private Server (VPS) dari Google Cloud Server. Penulis menggunakan nama domain https://hr.octagonstudio.com Setelah mendapatkan domain https://hr.octagonstudio.com langkah selanjutnya untuk publikasi web adalah mengupload file website. Dengan demikian Aplikasi HRIS ini telah terpublikasi.

3.5.2. Spesifikasi Hardware dan Software

Perangkat keras (Hardware) adalah seluruh komponen yang membentuk suatu sistem komputer dan peralatan lainnya yang minimum dan memungkinkan komputer dapat melaksanakan tugasnya. Bagian penting lain yang mendukung program adalah perangkat lunak (Software) yang digunakan dalam mengeksekusi program aplikasi serta sistem aplikasi yang akan digunakan untuk menjalankan program tersebut. 
Tabel 1.

Spesifikasi Hardware dan Software

\begin{tabular}{|l|l|}
\hline \multicolumn{1}{|c|}{ Kebutuhan } & \multicolumn{1}{c|}{ Keterangan } \\
\hline Sistem Operasi & $\begin{array}{l}\text { Microsoft Windows 7, } \\
\text { MacOS, Linux }\end{array}$ \\
\hline Browser & $\begin{array}{l}\text { Semua Browser } \\
\text { yang mendukung } \\
\text { HTML5 }\end{array}$ \\
\hline Processor & $\begin{array}{l}\text { Pentium Core 2 Duo, } \\
2.4 G h z\end{array}$ \\
\hline RAM & 1 GB \\
\hline Hardisk & 250 GB \\
\hline Keyboard & Standard \\
\hline Mouse & Standard \\
\hline Monitor & $14 "$ \\
\hline
\end{tabular}

\section{Kesimpulan}

Dalam bab ini penulis mengambil kesimpulan berdasarkan pembahasan pada bab-bab sebelumnya yang ada pada penelitian ini. Berikut kesimpulan yang didapat dari Aplikasi HRIS (Human Resource Information System) ini antara lain:

1. Aplikasi HRIS (Human Resource Information System) membuat proses perhitungan gaji karyawan menjadi lebih cepat karena aplikasi dapat menghitung gaji karyawan secara keseluruhan.

2. Pengajuan cuti yang dibuat karyawan menjadi lebih mudah, karena karyawan tinggal mengajukan cuti pada sistem dan atasan akan melakukan persetujuan jika memungkinkan.

3. Aplikasi HRIS (Human Resource Information System) dapat mengolah data pegawai dengan baik karena setiap pegawai memiliki hak akses untuk merubah dan melihat data pegawai tersebut.

\section{Saran}

Berdasarkan kesimpulan yang sudah dijabarkan sebelumnya, maka penulis memberikan beberapa saran yang dapat membantu dalam pengembangan Aplikasi HRIS (Human Resource Information System) ini sehingga menjadi lebih baik dan optimal.
1. Pengembangan Aplikasi HRIS (Human Resource Information System) dapat dilakukan dengan menambah fasilitas modul perekrutan karyawan dan modul penilaian karyawan.

2. Adanya fitur notifikasi secara real time agar informasi dapat diterima dengan cepat.

\section{Referensi}

Frangky, \& Devitra, J. (2016). Analisis Dan Perancangan Sistem Informasi Pengggajian Pada PT. Sumber Agrindo Sejahtera. Jurnal Manajemen Sistem Informasi, 185190.

Jonni , M., \& Husain, S. M. (2016). Perancangan Aplikasi Human Resource Information System (Hris) Berbasis Website Pada Pt. Super Tata Raya Steel. Jurnal Teknik UMT, 102-114.

Luthfi, F. (2017). Penggunaan Framework Laravel Dalam Rancang Bangun Modul Back-End Artikel Website Bisnisbisnis. ID. Jurnal Informatika Sunan Kalijaga, 2, 34-41.

Muhammad H.F, \& Niki P.S. (2018). Pengembangan Human Resource Information System (HRIS) untuk Optimalisasi Manajemen Sumber Daya Manusia di Perguruan Tinggi. JUPITER (Jurnal Pendidikan Teknik Elektro), 1-12.

Susanti, S., Junianto, E., \& Rachman, R. (2017). Implementasi Framework Laravel Pada Aplikasi Pengolah Nilai Akademik Berbasis Web. Jurnal Informatika, 4(1), 108-117.

Susanto, R., \& Andriana, A. D. (2016). Perbandingan Model Waterfall Dan Prototyping. Majalah Unikom, 14(1), 41-46.

Tjandra, S., \& Tambunan, S. T. B. (2019). Perancangan Website Human Resource Administration. Journal of Information System, Graphics, Hospitality and Technology, 1(01), 9-14.

Welim, Y. Y., \& lqbal, M. (2017). Pemodelan sistem informasi administrasi human resource development pada pt. Srikandi multi rental. Prosiding SINTAK, 341-347 